\title{
Effect of sildenafil citrate on brain central fatigue after exhaustive swimming exercise in rats
}

\author{
Sang-Seo Park', Tae-Woon Kim', Chang-Ju Kim', Seo-Youn Hong², Bo-Kyun Kim³, Young-Je Sim4, Mal-Soon Shin ${ }^{5, *}$ \\ 'Department of Physiology, College of Medicine, Kyung Hee University, Seoul, Korea \\ ${ }^{2}$ Department of Sports Medicine, Soonchunhyang University, Asan, Korea \\ ${ }^{3}$ Department of Emergency Technology, College of Health Science, Gachon University, Incheon, Korea \\ ${ }^{4}$ Department of Physical Education, Kunsan National University, Gunsan, Korea \\ ${ }^{5}$ College of Culture and Sports, Division of Global Sport Studies, Korea University, Sejong, Korea
}

Sildenafil citrate, a potent and selective inhibitor of phosphodiesterase type-5, is used clinically to treat erectile dysfunction and pulmonary arterial hypertension. We investigated the effect of sildenafil citrate on brain central fatigue through serotonin (5-hydroxytryptamine, 5-HT) synthesis after exhaustive swimming exercise in rats. The rats in the sildenafil citrate-treated groups received sildenafil citrate orally once a day for 14 consecutive days at respective dosage. On the 14 days after starting experiment, each animal was submitted to swimming test with intensity equivalent to overload. The exhaustion was defined as a state in which coordinated movements did not return to the water surface for breathing within $10 \mathrm{sec}$. Immunohistochemistry for 5-HT, tryptophan hydroxylase (TPH), and western blot for serotonergic type $1 \mathrm{~A}\left(5-\mathrm{HT} 1_{\mathrm{A}}\right)$ receptor and 5-HT transporter (5-HTT) were performed. Exhaustive swim- ming exercise increased 5-HT and TPH expressions in the dorsal raphe and sildenafil citrate suppressed 5-HT and TPH expressions in the exhaustive swimming exercise rats. Exhaustive swimming exercise increased $5-\mathrm{HT}_{\mathrm{A}}$ receptor and $5-\mathrm{HTT}$ expressions in the dorsal raphe and sildenafil citrate suppressed $5-\mathrm{HT} 1_{\mathrm{A}}$ receptor and $5-\mathrm{HTT}$ expressions in the exhaustive swimming exercise rats. The significant suppressing effect appeared in the $20-\mathrm{mg} / \mathrm{kg}$ sildenafil citrate. Sildenafil citrate might be proposed as a potential ergogenic aid through anticentral fatigue.

Keywords: Sildenafil citrate, Central fatigue, Exhaustive exercise, Serotonin

\section{INTRODUCTION}

Central fatigue is associated with regulation of serotonergic neurotransmitter system, such as serotonin (5-hydroxytryptamine, 5-HT), tryptophan hydroxylase (TPH), 5-HT receptor, and 5-HT transporter (5-HTT) (Cordeiro et al., 2017). 5-HT is an important neurotransmitter, which acts as a biochemical messenger and regulator of the brain function (Kim et al., 2017). Increase in the concentration of 5-HT in the brain during prolonged exercise impairs central nervous system functions and thus bring about a deterioration in exercise performance (Newsholme et al., 1992). 5-HT is modulated by many factors involved in the intrinsic regulation of central neurotransmission, which include TPH and se-

rotonergic type $1 \mathrm{~A}\left(5-\mathrm{HT}_{\mathrm{A}}\right)$ receptor (Foley et al., 2006). TPH catalyzes the rate-limiting step of serotonin biosynthesis in the dorsal raphe (Rind et al., 2000). 5-HT1 $1_{\mathrm{A}}$ receptor negatively regulates the activity of 5-HT neurons and is expressed in presynaptic autoreceptor on raphe neurons (Albert and Lemonde, 2004).

Sildenafil citrate, a potent and selective inhibitor of phosphodiesterase type-5, is used clinically to treat erectile dysfunction and pulmonary arterial hypertension (Mostafa, 2008). Sildenafil citrate increases local concentration of cyclic guanosine monophosphate, thus causing vasodilatation by relaxation of arterial wall smooth muscle fibers, especially in the corpus cavernosum and lungs (Harrold et al., 2000). Some studies have proposed the application of sildenafil citrate on several diseases, including myocardial in-

${ }^{*}$ Corresponding author: Mal-Soon Shin (D) https://orcid.org/0000-0002-7462-2211 College of Culture and Sports, Division of Global Sport Studies, Korea University, 2511 Sejong-ro, Sejong 30019, Korea

E-mail: malsoon@korea.ac.kr

This is an Open Access article distributed under the terms of the Creative Commons Attribution Non-Commercial License (http://creativecommons.org/licenses/by-nc/4.0/) which permits unrestricted non-commercial use, distribution, and reproduction in any medium, provided the original work is properly cited. 
farction, heart failure, and stroke (Guazzi et al., 2011; Kukreja et al., 2005). In addition, sildenafil citrate has been shown to improve exercise capacity in subjects with cardiopulmonary diseases (Kloner, 2004) and in healthy subjects in hypoxia (Hsu et al., 2006).

As sildenafil citrate is an effective pulmonary vasodilator (Schermuly et al., 2004), sildenafil citrate is a potent ergogenic aid during exercise performed under hypoxic conditions. However, anti-fatigue effect of sildenafil citrate is the tendency to focus on only peripheral fatigue in hypoxic conditions. Therefore, we investigated effects of sildenafil citrate administration on brain central fatigue after exhaustive swimming exercise in rats.

\section{MATERIALS AND METHODS}

\section{Animals}

Adult male Sprague-Dawley rats (8 weeks old) were used in this experiment. The experimental procedure was performed in accordance with the animal care guidelines of the National Institutes of Health and the Korean Academy of Medical Sciences. The rats were randomly divided into four groups ( $\mathrm{n}=10$ in each group): the control group, the exhaustive exercise group, the exhaustive exercise and $20-\mathrm{mg} / \mathrm{kg}$ sildenafil citrate-treated group, and the exhaustive exercise and 40-mg/kg sildenafil citrate-treated group. The rats in the sildenafil citrate-treated groups received sildenafil citrate (Sigma Chemical Co., St. Louis, MO, USA) orally once a day for 14 consecutive days at respective dosage. The rats in the control and exercise groups received normal saline orally once a day for 14 consecutive days.

\section{Exhaustive swimming exercise}

On the 14 days after starting experiment, each animal was submitted to exhaustive swimming test with intensity equivalent to overload (a metal ring weight attached to the animal's torso) of $10 \%$ of the body weight (Ding et al., 2009). The exhaustion was defined as a state in which coordinated movements did not return to the water surface for breathing within $10 \mathrm{sec}$.

\section{Tissue preparation}

After the exhaustive swimming exercise test, the rats were deeply anesthetized with Zoletil 50 anesthesia $(40 \mathrm{mg} / \mathrm{kg}$, intraperitoneally; Vibac Laboratories, Carros, France). After complete anesthesia, the rats were transcardially perfused with $0.05 \mathrm{M}$ phosphate-buffered saline (PBS), followed by $4 \%$ paraformaldehyde in $0.5 \mathrm{M}$ sodium phosphate buffer at $\mathrm{pH} 7.4$. The brain was removed, postfixed in the same fixative overnight, and transferred to a $30 \%$ sucrose solution for cryoprotection. Serial $40-\mu \mathrm{m}$-thick coronal sections were cut with a freezing microtome (Leica, Nussloch, Germany).

\section{Immunohistochemistry for 5-HT and TPH}

Immunohistochemistry for 5-HT and TPH was performed, according to the previously described method (Shin et al., 2017). An average of eight sections was selected in each brain region spanning from Bregma -7.30 to $-8.00 \mathrm{~mm}$. The sections were incubated in PBS for 10 min and they were next washed three times with PBS. The sections were then incubated in $1 \% \mathrm{H}_{2} \mathrm{O}_{2}$ for 30 min, and then they were incubated overnight with rabbit anti-5HT antibody (Oncogene Research Product, Cambridge, UK) at a dilution of 1:500 or with mouse anti-TPH antibody (Oncogene Research Product) at a dilution of 1:500. The sections were incubated for $1 \mathrm{hr}$ with biotinylated anti-rabbit secondary antibody or with anti-mouse secondary antibody (Vector Laboratories, Burlingame, CA, USA), and they were subsequently incubated with avidin-biotin-peroxidase complex (Vector Laboratories) for $1 \mathrm{hr}$ at room temperature. Immunoreactivity was visualized by incubating the sections in a solution consisting of $0.05 \% 3,3^{\prime}$-diaminobenzidine and $0.01 \% \mathrm{H}_{2} \mathrm{O}_{2}$ in $50 \mathrm{mM}$ Tris-buffer $(\mathrm{pH}, 7.6)$ for approximately $3 \mathrm{~min}$. The sections were finally mounted on gelatin-coated glass slides. The slides were air-dried overnight at room temperature, and the coverslips were mounted using Permount (Thermo Fisher Scientific Inc., Waltham, MA, USA).

\section{Western blot analysis}

Western analysis was performed, according to the previously described method (Shin et al., 2017). Dorsal raphe tissues were dissected. Sample tissues were stored at $-70^{\circ} \mathrm{C}$ until analysis. The tissues were lysed in ice-cold lysate buffer containing $50 \mathrm{mM}$ HEPES (pH, 7.5), $150 \mathrm{mM} \mathrm{NaCl}, 10 \%$ glycerol, $1 \%$ Triton $\mathrm{X}-100,1.5 \mathrm{mM}$ magnesium chloride hexahydrate, $1 \mathrm{mM}$ ethyleneglycol-bis-( $\beta$-aminoethyl ether)-N,N'-tetraacetic acid, $1 \mathrm{mM}$ phenylmethylsulfonyl fluoride, $2-\mu \mathrm{g} / \mathrm{mL}$ leupeptin, $1-\mu \mathrm{g} / \mathrm{mL}$ pepstatin, $1 \mathrm{mM}$ sodium orthovanadate, and $100 \mathrm{mM}$ sodium fluoride, after which the mixture was incubated for $30 \mathrm{~min}$ at $4^{\circ} \mathrm{C}$. The protein concentration was measured using a Bio-Rad colorimetric protein assay kit (Bio-Rad, Hercules, CA, USA). Protein of $30 \mu \mathrm{g}$ was separated on sodium dodecyl sulfate-polyacrylamide gels and transferred onto a nitrocellulose membrane (Whatman, Clifton, NJ, USA). Mouse anti- $\beta$ actin (1:1,000; Santa Cruz Biotechnology, Santa Cruz, CA, USA), rabbit anti- $5-\mathrm{HT} 1_{\mathrm{A}}$ receptor antibody (1:2,000; Abcam, Cambridge, UK) and rabbit anti-5- 
HTT (1:2,000; Abcam) were used as a primary antibody. A horseradish peroxidase-conjugated anti-mouse secondary antibody was used for $\beta$-actin, and an anti-rabbit secondary antibody was used for $5-\mathrm{HT} 1_{\mathrm{A}}$ receptor and 5-HTT. Band detection was performed using the enhanced chemiluminescence detection system (Santa Cruz Biotechnology). The bands were quantified using an Image-Pro Plus computer-assisted image analysis system (Media Cy- bernetics Inc., Bethesda, MD, USA).

\section{Statistical analysis}

Differences among the groups were evaluated using IBM SPSS Statistics ver. 23.0 (IBM Co., Armonk, NY, USA) by the one-way analysis of variance followed by Duncan post boc test. All values are expressed as the mean \pm standard error of the mean. Statistically

Table 1. Effect of sildenafil citrate on exhaustive swimming time in rats

\begin{tabular}{lcc}
\hline Exhaustive exercise group & Exhaustive exercise and $20 \mathrm{mg}$ sildenafil citrate-treated group & Exhaustive exercise and $40 \mathrm{mg}$ sildenafil citrate-treated group \\
\hline $18.85 \pm 0.69 \mathrm{~min}$ & $26.39 \pm 4.75 \mathrm{~min}^{*}$ & $20.89 \pm 0.90 \mathrm{~min}$ \\
\hline
\end{tabular}

The results are presented as the mean \pm standard error of the mean.

${ }^{*} P<0.05$ compared to the exhaustive exercise group.
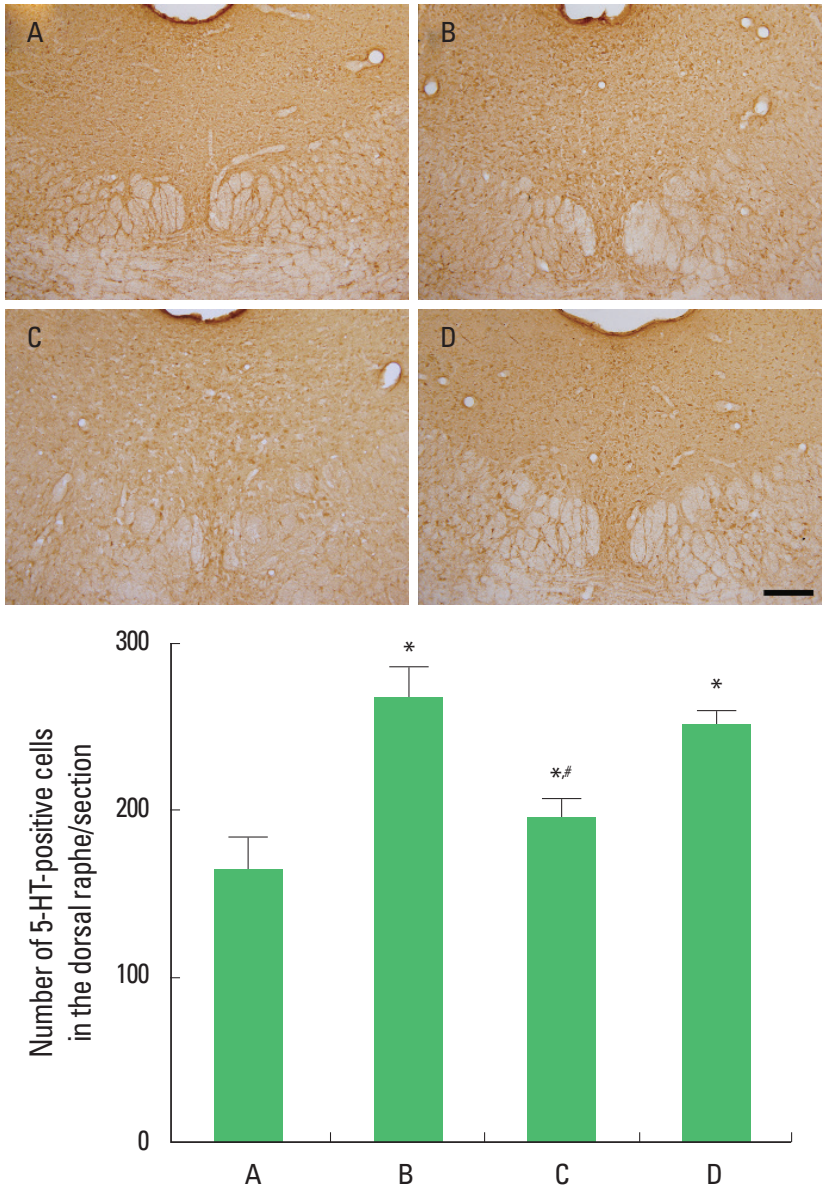

Fig. 1. Effects of sildenafil citrate on 5-hydroxytryptamine (5-HT). Upper panel: Photomicrographs showing 5-HT expressions in the dorsal raphe. Lower panel: The results are presented as the mean \pm standard error of the mean. The scale bar represents $250 \mu \mathrm{m}$. A, control group; $B$, exhaustive exercise group; $C$, exhaustive exercise and $20-\mathrm{mg} / \mathrm{kg}$ sildenafil treatment group; $\mathrm{D}$, exhaustive exercise and $40-\mathrm{mg} / \mathrm{kg}$ sildenafil treatment group. ${ }^{*} P<0.05$ compared to the control group. ${ }^{\#} P<0.05$ compared to the exhaustive exercise group.
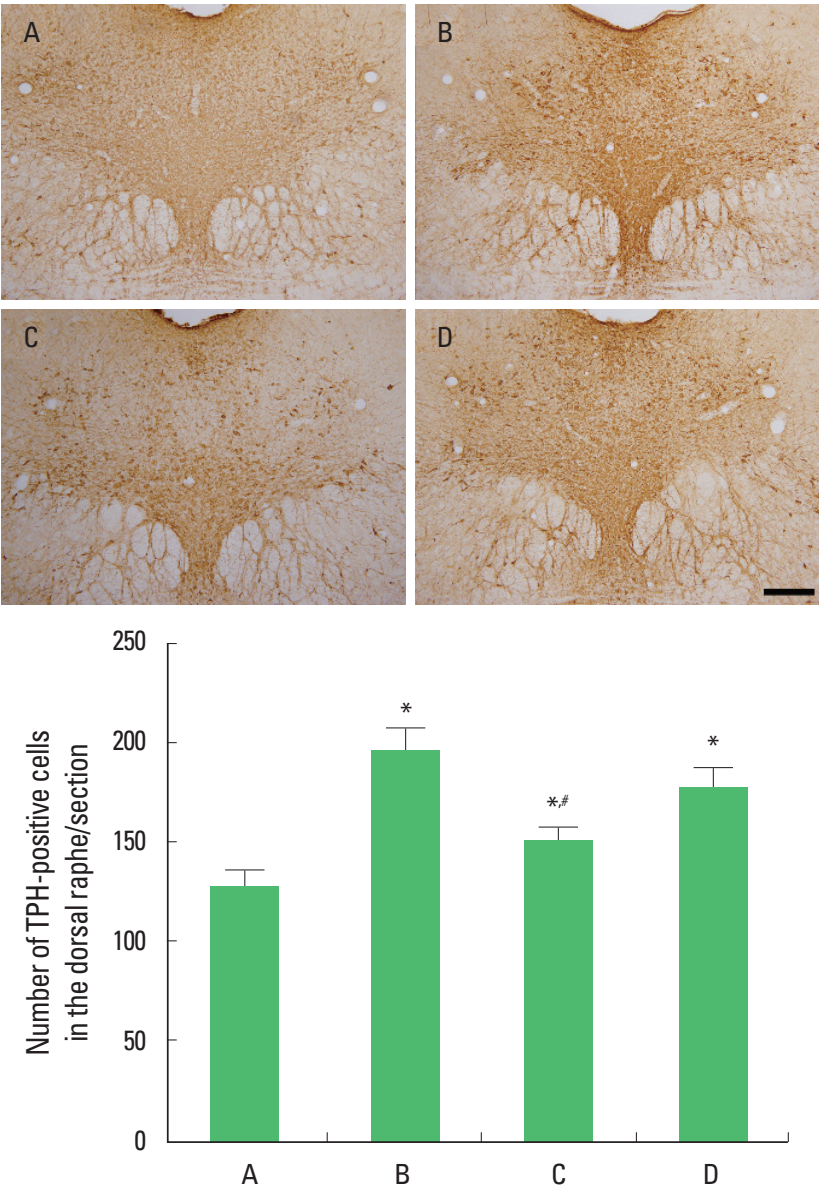

Fig. 2. Effects of sildenafil citrate on tryptophan hydroxylase (TPH). Upper panel: Photomicrographs showing TPH expressions in the dorsal raphe. Lower panel: The results are presented as the mean \pm standard error of the mean. The scale bar represents $250 \mu \mathrm{m}$. A, control group; B, exhaustive exercise group; C, exhaustive exercise and $20-\mathrm{mg} / \mathrm{kg}$ sildenafil treatment group; $\mathrm{D}$, exhaustive exercise and $40-\mathrm{mg} / \mathrm{kg}$ sildenafil treatment group. ${ }^{*} P<0.05$ compared to the control group. ${ }^{\sharp} P<0.05$ compared to the exhaustive exercise group. 
significant differences were established at $P<0.05$.

\section{RESULTS}

\section{Effect of sildenafil citrate on exhaustive swimming time}

Exhaustive swimming time is presented in Table 1. Exhaustive swimming time was increased in the exhaustive exercise and sildenafil citrate-treated groups than exhaustive swimming exercise group. The significant increasing effect on exhaustive swimming time appeared in the $20-\mathrm{mg} / \mathrm{kg}$ sildenafil citrate $(P<0.05)$.

\section{Effect of sildenafil citrate on 5-HT expression in the dorsal raphe}

Photomicrographs of 5-HT-positive cells in the dorsal raphe are presented in Fig. 1. Exhaustive swimming exercise increased 5-HT expression in the dorsal raphe $(P<0.05)$ and sildenafil citrate suppressed 5-HT expression in the exhaustive swimming exercise rats $(P<0.05)$. The significant suppressing effect appeared in the $20-\mathrm{mg} / \mathrm{kg}$ sildenafil citrate.

\section{Effect of sildenafil citrate on TPH expression in the dorsal raphe}

Photomicrographs of TPH-positive cells in the dorsal raphe are presented Fig. 2. Exhaustive swimming exercise increased TPH expression in the dorsal raphe $(P<0.05)$ and sildenafil citrate suppressed TPH expression in the exhaustive swimming exercise rats $(P<0.05)$. The significant suppressing effect appeared in the 20$\mathrm{mg} / \mathrm{kg}$ sildenafil citrate.

\section{Effect of treadmill exercise on $5-\mathrm{HT} 1_{\mathrm{A}}$ receptor and $5-\mathrm{HTT}$ expression in the dorsal raphe}

The $5-\mathrm{HT}_{\mathrm{A}}$ receptor and 5-HTT expressions are shown in Fig. 3. Exhaustive swimming exercise increased $5-\mathrm{HT} 1_{\mathrm{A}}$ receptor and 5 -HTT expressions in the dorsal raphe $(P<0.05)$ and sildenafil citrate suppressed $5-\mathrm{HT} 1_{\mathrm{A}}$ receptor and $5-\mathrm{HTT}$ expressions in the exhaustive swimming exercise rats $(P<0.05)$. The significant suppressing effect appeared in the $20-\mathrm{mg} / \mathrm{kg}$ sildenafil citrate.

\section{DISCUSSION}

Sildenafil citrate decreases pulmonary vascular resistance and increases $\mathrm{VO}_{2 \max }$ in hypoxic normal subjects (Ghofrani et al., 2004; Richalet et al., 2005). Galiè et al. (2005) reported that sildenafil citrate improved exercise capacity and pulmonary hemodynamic in patients with pulmonary arterial hypertension. Moreover, chronic sildenafil citrate treatment increased dopamine and
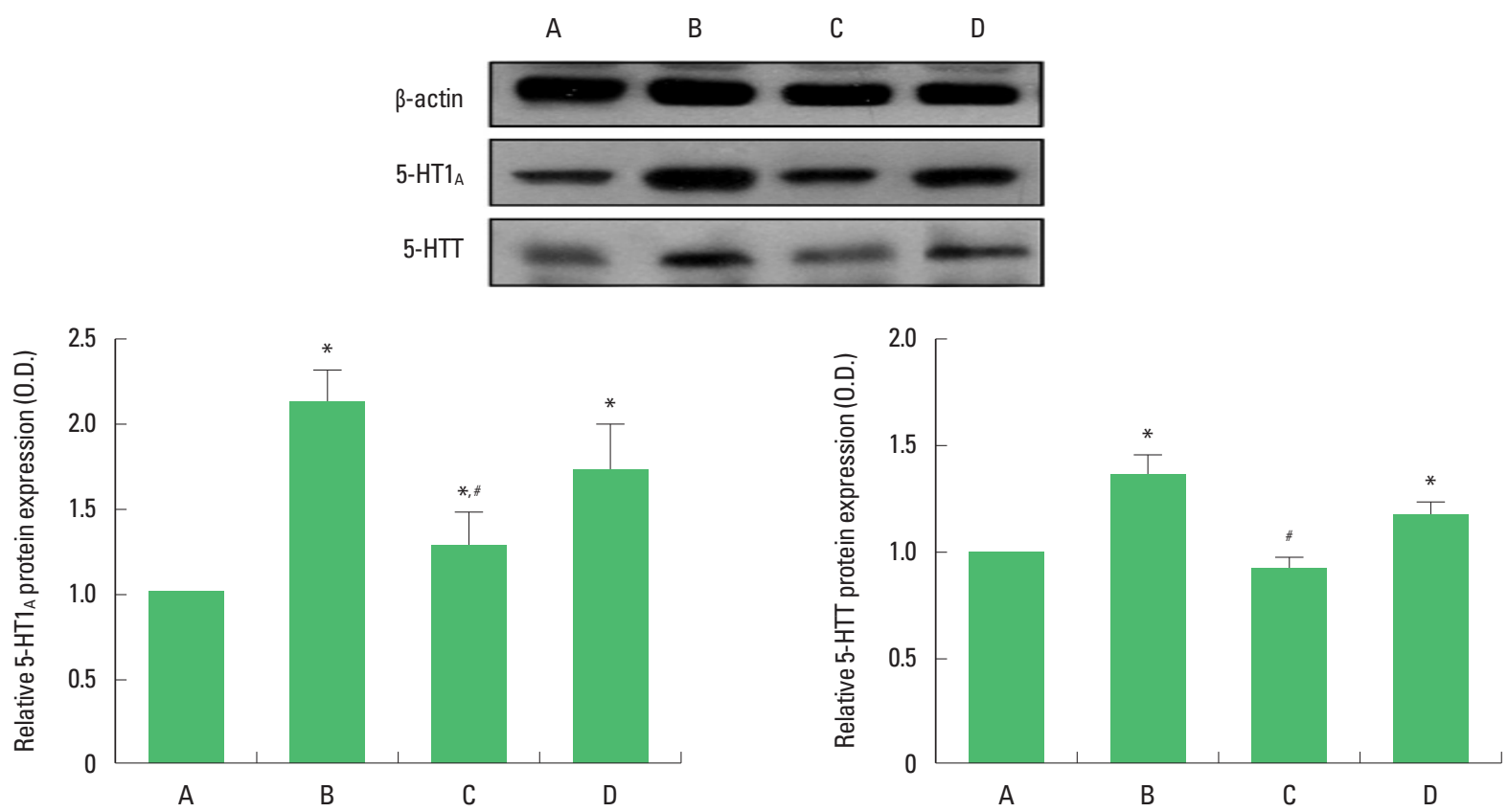

Fig. 3. Effects of sildenafil citrate on 5-hydroxytryptamine-1A $\left(5-H T 1_{A}\right)$ receptor and 5-hydroxytryptamine transporter (5-HTT) expressions in the dorsal raphe. Upper panel: The expressions of $5-\mathrm{HT}_{\mathrm{A}}$ and $5-\mathrm{HTT}$. Lower panel: The results are presented as the mean \pm standard error of the mean. $\mathrm{A}$, control group; $\mathrm{B}$, exhaustive exercise group; C, exhaustive exercise and 20-mg/kg sildenafil treatment group; D, exhaustive exercise and 40-mg/kg sildenafil treatment group. ${ }^{*} P<0.05$ compared to the control group. ${ }^{\sharp} P<0.05$ compared to the exhaustive exercise group. 
5-HT turnover rate in the medial preoptic area and nucleus accumben in the normal male rats (Kyratsas et al., 2013). In the present study, treatment of 20-mg sildenafil citrate prolonged exhaustive swimming time.

Central fatigue has been proposed the implication of various neurotransmitters such as serotonin, norepinephrine, and dopamine (Newsholme et al., 1992). Among these, serotonin is known to play the most important role in the pathogenesis of central fatigue (Kim et al., 2017). Increment in the 5-HT concentration in the brain is associated with mental fatigue (Davis et al., 2000). Increased concentration of 5-HT leads to the onset of fatigue (Soares et al., 2007), while decreased 5-HT concentration could delay the time to fatigue (Seo et al., 2011). In addition, exhaustive exercise increases 5-HT concentrations and then causes decrement of endurance performance (Caperuto et al., 2009). Inhibition of 5-HT production in the brain could increase endurance exercise performance (Seo et al., 2011). The synthesis of 5-HT is modulated by the hydroxylation of the amino acid tryptophan, which is the rate-limiting step catalyzed by TPH (Carkaci-Salli et al., 2006). Reduction in TPH expression decreases in 5-HT synthesis (Park et al., 2019). In the present study, treadmill exercise increased 5-HT synthesis and TPH expression in the dorsal raphe and 20-mg sildenafil citrate suppressed the exhaustive exercise-induced increase of 5-HT synthesis and TPH expression in the dorsal raphe.

Treadmill exercise upregulates the levels of $5-\mathrm{HT}$ and $5-\mathrm{HT} 1_{\mathrm{A}}$ receptor in rats with permanent middle cerebral artery occlusion (Lan et al., 2014). 5- $\mathrm{HT1}_{\mathrm{A}}$ receptor expression in the dorsal raphe was reduced by olfactory bulbectomy and treadmill exercise increased $5-\mathrm{HT} 1_{\mathrm{A}}$ receptor expression in the olfactory bulbectomized rats (Shin et al., 2017). Exhaustive exercise increased $5-\mathrm{HT}_{\mathrm{A}}$ receptor and $5-\mathrm{HTT}$ and colostrum serum treatment suppressed exhaustive exercise-induced $5-\mathrm{HT}_{\mathrm{A}}$ receptor and 5-HTT expression in the dorsal raphe (Kim et al., 2017). Primary pulmonary hypertension is caused by increased expression of the 5-HTT (Eddahibi et al., 2001). Degree of central fatigue depends on the function of the serotonin system (Kim et al., 2017; Maluchenko et al., 2009). In the present study, treadmill exercise increased $5-\mathrm{HT}_{\mathrm{A}}$ receptor and 5 -HTT expression in the dorsal raphe and 20-mg sildenafil citrate suppressed the exhaustive exercise-induced increase of $5-\mathrm{HT}_{\mathrm{A}}$ receptor and 5-HTT expressions in the dorsal raphe.

These results may support sildenafil citrate as an ergogenic aid to improve exercise performance. Sildenafil citrate might be proposed as a potential ergogenic aid through anticentral fatigue.

\section{CONFLICT OF INTEREST}

No potential conflict of interest relevant to this article was reported.

\section{ACKNOWLEDGMENTS}

This study was supported by the Ministry of Education of the Republic of Korea and the National Research Foundation of Korea (NRF-2017S1A5A8022823).

\section{REFERENCES}

Albert PR, Lemonde S. 5-HT1 ${ }_{\mathrm{A}}$ receptors, gene repression, and depression: guilt by association. Neuroscientist 2004;10:575-593.

Caperuto EC, dos Santos RV, Mello MT, Costa Rosa LF. Effect of endurance training on hypothalamic serotonin concentration and performance. Clin Exp Pharmacol Physiol 2009;36:189-191.

Carkaci-Salli N, Flanagan JM, Martz MK, Salli U, Walther DJ, Bader M, Vrana KE. Functional domains of human tryptophan hydroxylase 2 (hTPH2). J Biol Chem 2006;281:28105-28112.

Cordeiro LMS, Rabelo PCR, Moraes MM, Teixeira-Coelho F, Coimbra CC, Wanner SP, Soares DD. Physical exercise-induced fatigue: the role of serotonergic and dopaminergic systems. Braz J Med Biol Res 2017;50: e6432.

Davis JM, Alderson NL, Welsh RS. Serotonin and central nervous system fatigue: nutritional considerations. Am J Clin Nutr 2000;72(2 Suppl): 573S-578S.

Ding X, Tang K, Lu P, Putheti R. Antifatigue effects of polydatin from Chinese herb Polygonum Cuspidatum in swimming mice. Afr J Microbiol Res 2009;3:358-361.

Eddahibi S, Humbert M, Fadel E, Raffestin B, Darmon M, Capron F, Simonneau G, Dartevelle P, Hamon M, Adnot S. Serotonin transporter overexpression is responsible for pulmonary artery smooth muscle hyperplasia in primary pulmonary hypertension. J Clin Invest 2001; 108:1141-1150.

Foley TE, Greenwood BN, Day HE, Koch LG, Britton SL, Fleshner M. Elevated central monoamine receptor mRNA in rats bred for high endurance capacity: implications for central fatigue. Behav Brain Res 2006; 174:132-142.

Galiè N, Ghofrani HA, Torbicki A, Barst RJ, Rubin LJ, Badesch D, Fleming T, Parpia T, Burgess G, Branzi A, Grimminger F, Kurzyna M, Simonneau G; Sildenafil Use in Pulmonary arterial Hypertension (SUPER) Study Group. Sildenafil citrate therapy for pulmonary arterial hypertension. N Engl J Med 2005;353:2148-2157. 
Ghofrani HA, Reichenberger F, Kohstall MG, Mrosek EH, Seeger T, Olschewski H, Seeger W, Grimminger F. Sildenafil increased exercise capacity during hypoxia at low altitudes and at Mount Everest basecamp: a randomized, double-blind, placebo-controlled crossover trial. Ann Intern Med 2004;141:169-177.

Guazzi M, Vicenzi M, Arena R, Guazzi MD. Pulmonary hypertension in heart failure with preserved ejection fraction: a target of phosphodiesterase-5 inhibition in a 1-year study. Circulation 2011;124:164-174.

Harrold LR, Gurwitz JH, Field TS, Andrade SE, Fish LS, Jarry PD, Yood RA. The diffusion of a novel therapy into clinical practice: the case of sildenafil. Arch Intern Med 2000;160:3401-3405.

Hsu AR, Barnholt KE, Grundmann NK, Lin JH, McCallum SW, Friedlander AL. Sildenafil improves cardiac output and exercise performance during acute hypoxia, but not normoxia. J Appl Physiol 2006;100:2031-2040.

Kim TW, Kim CJ, Seo J. Effects of colostrum serum on the serotonergic system in the dorsal raphe nuclei of exercised rats. J Exerc Nutrition Biochem 2017;21:33-39.

Kloner RA. Cardiovascular effects of the 3 phosphodiesterase- 5 inhibitors approved for the treatment of erectile dysfunction. Circulation 2004; 110:3149-3155.

Kukreja RC, Salloum F, Das A, Ockaili R, Yin C, Bremer YA, Fisher PW, Wittkamp M, Hawkins J, Chou E. Pharmacological preconditioning with sildenafil: basic mechanisms and clinical implications. Vascul Pharmacol 2005;42:219-232.

Kyratsas C, Dalla C, Anderzhanova E, Polissidis A, Kokras N, Konstantinides K, Papadopoulou-Daifoti Z. Experimental evidence for sildenafil's action in the central nervous system: dopamine and serotonin changes in the medial preoptic area and nucleus accumbens during sexual arousal. J Sex Med 2013;10:719-729.

Lan X, Zhang M, Yang W, Zheng Z, Wu Y, Zeng Q, Liu S, Liu K, Li G. Effect of treadmill exercise on 5-HT, 5-HT1 $1_{\mathrm{A}}$ receptor and brain derived neurophic factor in rats after permanent middle cerebral artery occlusion. Neurol Sci 2014;35:761-766.

Maluchenko NV, Schegolkova JV, Kulikova MA, Timofeeva MA, Shlep- cova VA, Sysoeva OV, Tonevitsky AG. Gender effects on association of serotonin transporter gene polymorphism with symptoms of central fatigue. Bull Exp Biol Med 2009;147:462-465.

Mostafa T. Oral phosphodiesterase type 5 inhibitors: nonerectogenic beneficial uses. J Sex Med 2008;5:2502-2518.

Newsholme EA, Blomstrand E, Ekblom B. Physical and mental fatigue: metabolic mechanisms and importance of plasma amino acids. Br Med Bull 1992;48:477-495.

Park SS, Park HS, Jeong H, Kwak HB, No MH, Heo JW, Yoo SZ, Kim TW. Treadmill exercise ameliorates chemotherapy-induced muscle weakness and central fatigue by enhancing mitochondrial function and inhibiting apoptosis. Int Neurourol J 2019;23(Suppl 1):S32-9.

Richalet JP, Gratadour P, Robach P, Pham I, Déchaux M, JoncquiertLatarjet A, Mollard P, Brugniaux J, Cornolo J. Sildenafil inhibits altitude-induced hypoxemia and pulmonary hypertension. Am J Respir Crit Care Med 2005;171:275-281.

Rind HB, Russo AF, Whittemore SR. Developmental regulation of tryptophan hydroxylase messenger RNA expression and enzyme activity in the raphe and its target fields. Neuroscience 2000;101:665-677.

Schermuly RT, Kreisselmeier KP, Ghofrani HA, Yilmaz H, Butrous G, Ermert L, Ermert M, Weissmann N, Rose F, Guenther A, Walmrath D, Seeger W, and Grimminger F. Chronic sildenafil treatment inhibits monocrotaline-induced pulmonary hypertension in rats. Am J Respir Crit Care Med 2004;169:39-45.

Seo JH, Sung YH, Kim KJ, Shin MS, Lee EK, Kim CJ. Effects of Phellinus linteus administration on serotonin synthesis in the brain and expression of monocarboxylate transporters in the muscle during exhaustive exercise in rats. J Nutr Sci Vitaminol (Tokyo) 2011;57:95-103.

Shin MS, Park SS, Lee JM, Kim TW, Kim YP. Treadmill exercise improves depression-like symptoms by enhancing serotonergic function through upregulation of $5-\mathrm{HT} 1_{\mathrm{A}}$ expression in the olfactory bulbectomized rats. J Exerc Rehabil 2017;13:36-42.

Soares DD, Coimbra CC, Marubayashi U. Tryptophan-induced central fatigue in exercising rats is related to serotonin content in preoptic area. Neurosci Lett 2007;415:274-278. 